\title{
TUTURAN IMPERATIF DALAM NOVEL HIJRAH ITU CINTA KARYA ABAY ADHITYA
}

\author{
Aridazulvah $^{1}$, Retnowaty ${ }^{2}$, Maryatin ${ }^{3}$ \\ Universitas Balikpapan ${ }^{1}$, Universitas Balikpapan ${ }^{2}$, Universitas Balikpapan ${ }^{3}$ \\ pos-el: aridazulfah5@gmail.com ${ }^{1}$, retnowaty@uniba-bpn.ac.id ${ }^{2}$, maryatin@uniba-bpn.ac.id ${ }^{3}$
}

\begin{abstract}
ABSTRAK
Penelitian ini berfokus pada penggunaan tuturan imperatif yang terdiri dari 17 indikator. Tuturan imperatif ini merujuk pada dialog dan narasi dalam novel Hijrah itu Cinta. Tujuan penelitian ini untuk mendeskripsikan tuturan imperatif dalam novel Hijrah itu Cinta karya Abay Adhitya. Penelitian ini menggunakan jenis penelitian kualitatif deskriptif. Secara teoritis pendekatan yang digunakan dalam penelitian ini adalah pendekatan pragmatik. Data penelitian ini berupa dialog dan narasi. Sumber penelitian menggunakan novel. Pengumpulan data menggunakan metode simak dan catat. Instrumen penelitian ini adalah tabel pengkodean data (kartu data) yang dibantu dengan alat tulis. Pemeriksaan keabsahan data menggunakan ketekunan pengamat dan teman sejawat. Tuturan imperatif yang ditemukan dalam novel Hijrah itu Cinta ada 10 indikator yaitu, tuturan imperatif perintah, suruh, permintaan, permohonan, desakan, persilaan, ajakan, larangan, permintaan izin, dan harapan. Hasil penelitian ini menunjukkan bahwa terdapat wujud pragmatik imperatif dalam novel Hijrah itu Cinta Karya Abay Adhitya sebanyak 51 data, (1) tuturan imperatif perintah sebanyak 6 data, (2) imperatif suruhan sebanyak 3 data, (3) imperatif permintaan sebanyak 9 data, (4) imperatif permohonan sebanyak 2 data, (5) imperatif desakan sebanyak 3 data, (6) imperatif persilaan sebanyak 2 data, (7) imperatif ajakan sebanyak 2 data, (8) imperatif permintaan izin sebanyak 7 data, (9) imperatif larangan sebanyak 14 data, (10) imperatif harapan 3 data. Hal tersebut diperoleh berdasarkan analisis data yang dilakukan secara berulang-ulang.
\end{abstract}

\section{Kata Kunci: pragmatik, tuturan imperatif, novel}

\begin{abstract}
This study focuses on the use of imperative speech which consists of 17 indicators. This imperative speech refers to the dialogue and narrative in the novel Hijrah is Cinta. The purpose of this research is to describe the imperative utterances in Abay Adhitya's novel Hijrah's Cinta. This research uses descriptive qualitative research. Theoretically, the approach used in this research is a pragmatic approach. The research data is in the form of dialogue and narration. Research sources using novels. Data collection used the observation and note method. The research instrument was a data coding table (data card) which was assisted by writing instruments. Checking the validity of the data used the persistence of observers and peers. Imperative speech found in the novel Hijrah Cinta has 10 indicators, namely, imperative speech, orders, orders, requests, requests, insistences, invitations, invitations, prohibitions, requests for permission, and hopes. The results of this study indicate that there is an imperative pragmatic form in the Hijrah novel Cinta Karya Abay Adhitya as many as 51 data, (1) imperative command speech is 6 data, (2) imperative orders are 3 data, (3) demand imperative is 9 data, (4) 2 data imperative requests, (5) 3 data imperative demands, (6) 2 data imperative requests, (7) 2 data imperative requests, (8) 7 data imperative requests, (9) prohibition imperatives as many as 14 data, (10) imperative expectations 3 data. This was obtained based on data analysis which was carried out repeatedly.
\end{abstract}

Keywords: pragmatics, imperative speech, novel 


\section{PENDAHULUAN}

Bahasa merupakan suatu alat komunikasi yang mana memiliki peranan yang cukup penting dalam kehidupan sehari-hari, dimana dengan bahasa seseorang dapat dengan mudah untuk menyampaikani ide, gagasan, dan pemikirannya pada orang lain. Adapun selain menjadi alat untuk berkomunikasi bahasa juga bisa dibedakan menjadi dua bentuk yaitu bentul lisan dan bentuk tulisan. Chaer (2010, p. 14) mengatakan bahasa, baik sebagai langage maupun langue, lazim didefinisikan sebagai sebuah sistem lambang bunyi yang bersifat arbitrer yang digunakan manusia sebagai alat komunikasi atau alat interaksi sosial. Selain itu, dalam sebuah karya sastra banyak pengarang yang menyampaikan ide, gagasan dan pemikirannya baik itu dalam bentuk puisi, cerpen, novel dan lainnya.

Novel merupakan salah satu karya sastra bentuk prosa yang dapat digunakan untuk menyampaikan suatu ide, gagasan, maupun pemikiran dari seseorang. Banyak dari pengarang yang terkadang menceritakan langsung kisah hidupnya atau juga banyak menceritakan mengenai pengalaman-pengalaman hidup dari masyarakat sekitar, yang nantinya diolah menjadi sebuah karangan cerita yang apik. Secara garis besar karya sastra dibagi menjadi tiga yaitu puisi, prosa, dan drama. Karya sastra merupakan hasil karya manusia yang mengandung imajinasi dengan menggunakan bahasa sebagai medianya. Sastra itu sendiri lahir disebabkan oleh dorongan manusia untuk menunjukan kreativitasnya. Kemunculan karya sastra di dunia ini memunculkan pula kajian-kajian yang menjadi karya sastra sebagai objeknya. Hal ini karena, karya sastra memiliki maksud tersirat yang ingin disampaikan oleh penulisnya.

Seringkali tuturan yang disampaikan oleh pengarang lewat karya sastranya memiliki makna pragmatik. Rahardi (2005, p. 48) mengatakan pragmatik sebagai studi bahasa yang mempelajari relasi bahasa dengan konteksnya. Konteks yang dimaksud tergramatisasi dan terkodifikasi sehingga tidak dapat dilepaskan dari struktur bahasanya. Begitu pula dengan tuturan imperatif wujudnya memang tidak selalu sesuai dengan kontruksinya, melainkan ditentukan lagi sesuai dengan konteksnya.

Tuturan imperatif merupakan kalimat yang meminta pendengar atau pembaca melakukan suatu tindakan. Rahardi (2005, p. 93-117) menjelaskan bahwa terdapat beberapa tuturan imperatif yaitu imperatif perintah, suruh, permintaan, permohonan, desakan, bujukan, imbauan, persilaan, ajakan, permintaan izin, mengizinkan, larangan, harapan, umpatan, imperatif pemberian ucapan selamat, anjuran, dan "ngelulu". Selain itu, imperatif memiliki peranan yang penting dalam kehidupan sehari-hari. Dimana dengan adanya tuturan imperatif mitra tutur dapat lebih memahami maksud bahasa ataupun kalimat yang oranglain sampaikan dan dapat mempermudah jalannya komunikasi antar penutur dan mitra tutur. Sedangkan, pada novel imperatif juga memiliki peranan yang penting, yang mana pembaca akan menjadi lebih mudah memahami maksud dari kalimat yang disampaikan oleh pengarang. Adapun salah satu contoh tuturan imperatif pada novel Hijrah itu Cinta, seperti data berikut:

a. Tuturan A : "Sat,

kapan kamu mau berhenti dan

berubah? Kasihan perempuan-

perempuan yang kamu taklukkan, lalu kamu tinggalkan begitu saja.

b. Tuturan B : "Enggak banyak, kok Ngga, kamu jangan lebay. Lagian semuanya dilakukan atas suka sama suka.

Tuturan di atas, dituturkan oleh teman Satria kepada Satria yang sedang mencoba mendapatkan wanita untuk ia jadikan pelampiasan nafsunya.

Tuturan A termasuk dalam kalimat perintah yang mengandung makna permintaan agar mitra tutur mau 
menghendaki apa yang diinginkan penutur yaitu seorang teman yang meminta kepada Satria agar dapat berhenti untuk melakukan hal-hal yang tidak baik terutama mempermainkan perempuan. Namun, Satria tidak menghiraukan apa yang dikatakan oleh temannya tersebut dan masih saja mempermaikan wanita dengan alasan suka sma suka.

Pada contoh di atas, dapat diketahui pentingnya tuturan imperatif pada novel yaitu dengan adanya tuturan imperatif peneliti dapat mengetahui lebih detail maksud dari apa yang dituturkan dalam novel, tidak hanya sekedar membaca, tetapi peneliti juga bisa mengetahui wujud dari tuturan tersebut tuturan tersebut.

Hal yang mendasari penelitian ini adalah tuturan yang bervariatif atau beragam yang digunakan oleh pengarang dalam novel Hijrah itu Cinta karya Abay Adhitya. Penelitian ini didukung oleh beberapa penelitian mengenai tindak tutur yang telah dilaksanakan oleh AlHumairah, Retnowaty \& Ratnawati (2020) serta penelitian oleh Wahyuni \& Retnowaty (2018). Namun teori yang digunakan pada penelitian ini berbeda. Teori yang digunakan pada kedua penelitian adalah teori tindak tutur secara umum dan pada penelitian ini menggunakan teori tindak tutur yang lebih spesifik yaitu tuturan imperatif. Penelitian ini juga memiliki teori yang berbeda dengan penelitian yang telah dilaksanakan oleh Astuti, Retnowaty, \& Maulida (2020) yang menggunakan teori strategi tindak tutur penolakan walaupun temanya sama sama terkait tentang tindak tutur.

Penelitian yang paling mendekati tuturan imperatif telah dilakukan oleh beberapa peneliti yakni Hodairiyah \& Utama (2019), Ramaniyar (2017), Sulhan (2019) dan namun, milik Asrul, dkk (2019) akan dijelaskan persamaan dan perbedaannya dengan penelitian ini. Penelitian Asrul dkk (2019) yang berjudul 'Analisis Tuturan Imperatif Pada Media Luar Ruang Di Kabupaten Sambas: Kajian Pragmatik". Hasil dari penelitian yang di lakukan di kabupaten Sambas pada media luar ruang terdiri dari 9 jenis yaitu tuturan yang bermakna pragmatik imperatif perintah berjumlah 8 data, tuturan yang bermakna pragmatik imperatif bujukan 1 data, tuturan yang bermakna imperatif imbauan 11 data, imperatif ajakan 10 data, mengizinkan 2 data, larangan 8 data, harapan 2 data, dan tuturan yang bermakna imperatif anjuran 5 data.

Persamaan penelitian yang akan dilaksanakan dengan penelitian Asrul dkk yaitu sama-sama mengkaji mengenai bentuk tuturan imperatif. Perbedaan pada penelitian yang akan dilaksanakan dengan penelitian Asrul dkk yakni terdapat pada objek yang diambil oleh masing-masing peneliti, pada peneliti sekarang menggunakan novel Hijrah itu Cinta sebagai objeknya sedangkan Asrul dkk menggunakan Media Luar Ruang Di Kabupaten Sambas sebagai objeknya

Peneliti akan mengungkapkan lebih lanjut tentang bagaimana wujud tuturan imperatif yang terdapat dalam novel Hijrah itu Cinta karya Abay Adhitya. Novel ini termasuk novel baru yang telah banyak dibaca dan banyak dari pembacanya terinspirasi akan cerita yang dituliskan oleh Abay Adhitya terutama kalangan anak muda. Hal ini, sesuai dengan review dan respon dari pembaca pada instagram Abay Adhitya (@kangabay_). Selain itu, novel Hijrah itu Cinta dengan tuturan imperatif yang digunakan dalam novel tersebut memiliki kaitan yang sangat penting karena, tuturan imperatif tersebut membuat cerita dalam novel menjadi lebih menarik. Tuturan imperatif yang terdapat dalam novel Hijrah itu Cinta memiliki tuturan yang tidak biasa yaitu tuturan yang memerintah pada kebaikan sehingga dapat dijadikan pelajaran untuk para pembacannya.

Tuturan yang digunakan novel Hijrah itu Cinta sendiri memiliki kalimat yang dapat dibilang sangat beragam dan bervariasi untuk diteliti. Berdasarkan latar belakang di atas, maka peneliti melakukan penelitian yang berjudul "Tuturan 
Imperatif Dalam Novel Hijrah Itu Cinta Karya Abay Adhitya".

\section{METODE PENELITIAN}

Pendekatan yang digunakan dalam penelitian ini yaitu pendekatan pragmatik, pendekatan pragmatik ini memiliki kaitan yang erat dengan penggunaan bahasa. Peneliti akan menganalisis mengenai pemakaian bahasa dalam konteksnya atau pada situasi tertentu dengan kata lain pragmatik akan menelaah maksud dari apa yang penutur tuturkan. Selaras dengan hal tersebut, Levinson (Rahardi, 2005, p. 48) mendefinisikan pragmatik sebagai studi bahasa yang mempelajari relasi bahasa dengan konteksnya. Konteks yang dimaksud tergramatisasi dan terkodifikasi sehingga tidak dapat dilepaskan dari struktur bahasannya dengan pendekatan pragmatik ini maka data dapat dilakukan dengan mengidentifikasi tuturan imperatif yang terdapat dalam novel Hijrah itu Cinta karya Abay Adhitya.

Strauss dan Corbin (Sujarweni, 2019, p. 19) mengatakan penelitian kualitatif adalah jenis penelitian yang menghasilkan penemuan-penemuan yang tidak dapat dicapai (diperoleh) dengan menggunakan prosedur-prosedur statistik atau cara-cara lain dari kualitatif (pengakuan). Penelitian kualitatif secara umum dapat digunakan untuk penelitian tentang kehidupan masyarakat, sejarah, tingkah laku aktivitas sosial, dan lain-lain. Jenis penelitian kualitatif ini akan digunakan oleh peneliti untuk mendeskripsikan data yang ditemukan oleh peneliti.

Bogdan dan Taylor (Sujarweni, 2019, p.19) menjelaskan bahwa penelitian kualitatif adalah salah satu prosedur penelitian yang menghasilkan data deskriptif berupa ucapan atau tulisan dan prilaku orang-orang yang diamati. Penelitian ini merupakan jenis penelitian kualitatif dengan menggunakan metode deskriptif karena, data yang diperoleh tidak berupa angka-angka, melainkan hasil analisisnya berbentuk deskriptif berbentuk dialog dan narasi pada novel Hijrah itu Cinta karya Abay Adhitya.

Dari beberapa penjelasan di atas, maka dapat disimpulkan bahwa penelitian kualitatif adalah penelitian yang bersifat deskriptif cenderung menggunakan analisis. Selain itu, bisa juga dikatakan sebuah metode yang menekankan pada aspek pemahaman lebih mendalam terhadap suatu masalah daripada melihat permasalahan, juga lebih menonjolkan dalam bentuk proses dan makna.

\section{HASIL DAN PEMBAHASAN}

Hasil penelitian yang disajikan pada bab ini sesuai dengan tujuan dari penelitian. Tujuan penelitian sendiri yaitu adalah mendeskripsikan wujud imperatif yang terdapat dalam novel Hijrah itu Cinta karya Abay Adhitya. Berdasarkan ujaran yang dituturkan oleh tokoh dalam novel Hijrah itu Cinta yang berbentuk sebuah dialog dan narasi.

Novel sendiri merupakan salah satu karya sastra bentuk prosa yang dapat digunakan untuk menyampaikan suatu ide, gagasan, maupun pemikiran dari seseorang, dimana banyak dari pengarang yang terkadang menceritakan langsung kisah hidupnya atau juga banyak menceritakan mengenai pengalamanpengalaman hidup dari masyarakat sekitar yang mana nantinya diolah menjadi sebuah karangan cerita yang apik sedangkan.

Tuturan imperatif sendiri dapat diartikan sebagai bentuk perintah ataupun perasaan yang ada dalam diri para tokoh untuk menyuarakan pendapatnya, tuturan yang diungkapkan oleh penutur bertujuan agar lawan tutur melakukan sesuatu yang diinginkan oleh penutur dan dalam bertutur kita juga harus menyampaikan tuturan kita sesuai dengan konteks tuturan, agar terciptanya sikap saling menghormati dan menghargai satu sama lain. 
Tabel 3. Tuturan yang mengandung makna pragmatik imperatif dalam novel Hijrah itu Cinta Karya Abay Adhitya

\begin{tabular}{|l|l|c|c|}
\hline No & \multicolumn{1}{|c|}{$\begin{array}{c}\text { Tuturan } \\
\text { Pragmatik } \\
\text { Imperatif }\end{array}$} & $\begin{array}{c}\text { Frek } \\
\text { uensi }\end{array}$ & $\%$ \\
\hline 1 & Imperatif Perintah & 6 & $11,7 \%$ \\
\hline 2 & Imperatif Suruhan & 3 & $5,8 \%$ \\
\hline 3 & $\begin{array}{l}\text { Imperatif } \\
\text { Permintaan }\end{array}$ & 9 & $17,6 \%$ \\
\hline 4 & $\begin{array}{l}\text { Imperatif } \\
\text { Permohonan }\end{array}$ & 2 & $3,9 \%$ \\
\hline 5 & Imperatif Desakan & 3 & $5,8 \%$ \\
\hline 6 & Imperatif Bujukan & 0 & $0 \%$ \\
\hline 7 & Imperatif Imbauan & 0 & $0 \%$ \\
\hline 8 & Imperatif Persilaan & 2 & $3,9 \%$ \\
\hline 9 & Imperatif Ajakan & 2 & $3,9 \%$ \\
\hline 10 & $\begin{array}{l}\text { Imperatif } \\
\text { Permintaan Izin }\end{array}$ & 7 & $13,7 \%$ \\
\hline 11 & $\begin{array}{l}\text { Imperatif } \\
\text { Mengizinkan }\end{array}$ & 0 & $0 \%$ \\
\hline 12 & Imperatif Larangan & 14 & $27,4 \%$ \\
\hline 13 & Imperatif Harapan & 3 & $5,8 \%$ \\
\hline 14 & Imperatif Umpatan & 0 & $0 \%$ \\
\hline 15 & $\begin{array}{l}\text { Imperatif Pemberian } \\
\text { Ucapan Selamat }\end{array}$ & 0 & $0 \%$ \\
\hline 16 & Imperatif Anjuran & 0 & $0 \%$ \\
\hline 17 & Imperatif "Ngelulu" & 0 & $0 \%$ \\
\hline \multicolumn{2}{|l|}{ Jumlah } & 51 & $100 \%$ \\
\hline
\end{tabular}

Berdasarkan tabel tersebut, jumlah keseluruhan wujud pragmatik imperatif yang terdapat dalam novel Hijrah itu Cinta Karya Abay Adhitya yaitu meliputi: wujud pragmatik imperatif perintah sebanyak 6 data dengan presentase sebesar 11,7\%, wujud pragmatik imperatif suruhan sebanyak 3 data dengan presentase sebesar $5,8 \%$, wujud pragmatik imperatif permintaan sebanyak 9 data dengan presentase $17,6 \%$, wujud pragmatik imperatif permohonan sebanyak 2 data dengan presentase sebessar 3,9\%, wujud pragmatik imperatif desakan sebanyak 3 data dengan presentase sebessar 5,8\%, wujud pragmatik imperatif persilaan sebanyak 2 data dengan presentase sebesar $3,9 \%$, wujud pragmatik imperatif ajakan sebanyak 2 data dengan presentase sebesar $3,9 \%$, wujud pragmatik imperatif permintaan izin sebanyak 7 data dengan presentase sebesar 13,7\%, wujud pragmatik imperatif larangan sebanyak 14 data dengan presentase sebesar 27,4\%, wujud pragmatik imperatif harapan 3 data dengan presentase $5,8 \%$.

Tuturan imperatif yang tidak ditemukan yaitu imperatif bujukan, imbauan, mengizinkan, umpatan, pemberian ucapan selamat, anjuran, dan "ngelulu". Hal tersebut diperoleh berdasarkan penyelesaian data yang telah dilakukan sebagai bagian dari proses analisis melalui ketekunan dari peneliti sendiri dengan membaca secara teliti datadata, baik itu berupa dialog dan narasi pada tuturan tokoh dalam novel Hijrah itu Cinta Karya Abay Adhitya.

Beberapa contoh pembahasan tuturan imperative tokoh dalam novel Hijrah itu Cinta Karya Abay Adhitya yaitu

\section{a. Tuturan Yang Mengandung Makna Pragmatik Imperatif Perintah}

Data : (Ipr/26/1.01)

Masih tergiang ucapan Paman tadi sore dan itu membuat air mata Ibu menderas. Sementara bayangan kematian yang masuk ke mimpi dan meneror tidurnya akhirakhir ini kembali hadir dan membuatnya ketakutan.Ibu teringat nasihat Ustadz dalam kajian di masjid kompleks rumahnya

Ustadz : "Berzikirlah ... ingatlah Allah maka hati akan menjadi tenang, dan zikir terbaik adala memperbaak Istigfar"

Berulang-ulang Ibu mengucapkan kalimat istigfar sepenuh hati. Tiap lafaz membekas dan terasa mengalir dari kerongkongan hingga merasuk ke dada. Ketenangan perlahan Ibu rasakan, hingga akhirnya ia tertidur lelap.

Tuturan pada data (Ipr/26/1.01) diungkapkan oleh ustadz kepada para jamaahnya mengenai bagaimana cara agar hati menjadi lebih tenang, dan ustadz menyuruh dengan memperbanyak zikir juga selalu mengingat Allah, dengan begitu hati akan menjadi lebih tenang dan selalu merasa dalam lindungan Allah, hal itulah yang selalu teringat oleh ibu Senja 
saat ia mulai teringat akan kematian yang selalu menerornya atas kesalahankesalahan yang telah ia perbuat.

Berdasarkan data (Ipr/26/1.01) tuturan tersebut termasuk ke dalam tuturan yang mengandung makna pragmatik imperatif perintah karena ustadz menyuruh para jemaah agar banyak-banyak mengucapkan kalimat zikir juga selalu mengingat Allah, dengan begitu setiap orang yang mengamalkannya akan merasa hatinya lebih tenang dan lebih dekat dengan penciptanya yaitu Allah. Adapun kutipan data yang mendukung hal tersebut, "Berzikirlah ... ingatlah Allah maka hati akan menjadi tenang". Pada kutipan ini sangat jelas bahwa ustadz menyuruh para jemaahnya agar banyak-banyak berzikir dan selalu mengingat Allah. Selain itu didukung juga dengan penggunaan partikel "-lah" untuk mempertegas maksud dalam tuturan tersebut.

\section{b. Tuturan Yang Mengandung Makna Pragmatik Imperatif Suruhan}

Data : (Is/45-46/2.02)

Fajar sangat bersyukur. Meskipun begitu berat perjuangan hidupnya dan ibunya selama ini dia merasakan berapu Allah Mahabaik, tak pernah meninggalkan dia sedetik pun dan sempatkanlah biasakanlah melaksanakan shalat Dhuha setiap hari. Nikmati matahari pagi yang tersenyum indah Berdoalah kepada-Nya dan bersyukurlah atas nikmat yang telah Allah berikan. Karena ada begitu banyak orang yang mungkin kehidupannya lebih sulit darimu Dan. ada banyak kenikmatan Tuhan yang mungkin selama ini luputki syukuri. Rasakan perubahan kemudahan serta kelimpahan rezeki dalam hidupmu.

Ustadz Firdaus : "Orang-orang yang sukses di dunia, tetapi tetap berorientasi pada akhirat itu hidupnya berkah, tenang, dan penuh rasa syukur. Salah satunya, karena mereka membiasakan diri untuk shalat Dhuha. Coba deh, Adik-adik mahasiswa biasain.

Tuturan pada data (Is/45-46/2.02) diungkapkan oleh Ustadz Firdaus kepada para mahasiswa agar dapat membiasakan diri atau menyempatkan untuk melaksanakan shalat Dhuha, dengan begitu hidup akan terasa lebih berkah, tenang dan selalu dipenuhi oleh rasa syukur.

Berdasarkan data (Is/45-46/2.02) tuturan tersebut termasuk ke dalam tuturan yang mengandung makna pragmatik imperatif suruhan karena Ustadz Firdaus menyuruh agar para mahasiswa dapat membiasakan diri untuk shalat Dhuha. Dengan selalu melakukan shalat Dhuha, hati yang melakukannya akan merasa lebih berkah atas apa yang dilakukannya dan juga merasa lebih tenang dan slalu bersyukur atas apa yang telah diberikan. Adapun kutipan data yang mendukung hal tersebut, "Salah satunya, karena mereka membiasakan diri untuk shalat Dhuha. Coba deh, Adik-adik mahasiswa biasain". Selain itu didukung kata "coba" dalam tuturannya yang menjadi penanda dari tuturan imperatif suruhan .

\section{c. Tuturan Yang Mengandung Makna Pragmatik Imperatif Permintaan}

Data : (Ipm/61/1.03)

Ayah : Nak, tolong cintai dan jaga

Ibumu selalu. Ayah pun selalu mendoakan Ibumu agar dijaga olehNya, selalu mendapatkan kebaikan, hidayah, rida, dan sebuah akhir kehidupan yang indah (husnul khotimah)".

Tuturan pada data (Ipm/61/1.03) tuturan yang disampaikan oleh ayah Senja melalui surat dengan menuliskan pesan bahwa ayahnya ingin agar Senja dapat selalu menjaga dan mencintai Ibunya walau dalam keadaan apapun karena ayahnya tidak dapat lagi bertemu ibu dan juga Senja, ayahnya hanya bisa mendokan keduanya dari jauh agar mereka selalu dalam lindungan Allah.

Berdasarkan data (Ipm/61/1.03), tuturan tersebut termasuk ke dalam tuturan yang mengandung makna pragmatik imperatif permintaan karena ayah Seja meminta agar Senja selalu menjaga ibunya juga mencintai ibunya karena ayahnya hanya 
bisa mendoakan yang terbaik untuk ibunya. Adapun kutipan data yang mendukung hal tersebut, "Nak, tolong cintai dan jaga Ibumu selalu. Ayah pun selalu mendoakan Ibumu agar dijaga olehNya, selalu mendapatkan kebaikan , hidayah, rida, dan sebuah akhir kehidupan yang indah (husnul khotimah)" . Selain itu , didukung kata "tolong" dalam tuturannya yang menjadi penanda dari tuturan imperatif permintaan untuk memberi penekanan dari tuturan tersebut.

\section{d. Tuturan Yang Mengandung Makna Pragmatik Imperatif Permohonan}

Data : (Iphn/46/1.04)

Ketika menafsirkan Surah Adh-Dhuha, tiba-tiba Fajar teringat sebuah nama. Dia bangkit dari tempat tidurnya dan berjalan menuju lemari. Di ambilnya juz amma berwarna merah yang selama ini dia simpan dengan baik. Di tatapnya lekatlekat juz amma bertuliskan nama wanita yang sudah dia tak ingat paras rupanya. Betapa dia ingin dia bertemu dengan sang pemilik juz amma itu.

Fajar : "Ya Allah pertemukan aku dengan dia, sekali saja. Agar aku bisa mengembalikan juz amma ini kepadanya. Agar aku bisa berterimakasih kepadanya atas kebaikan yang telah dia lakukan padaku dulu, yang membuatku bisa lebih mengenal-Mu."

Tuturan pada data (Iphn/46/1.04) dituturkan oleh Fajar kepada Allah melalui sebuah doa mengenai keinginannya agar dapat dipertemukan oleh Senja dan Fajar sangat ingin sekali dapat segera mengembalikan juz ama yang ia pinjam dari Senja yang belum dapat ia kembalikan kepada pemiliknya yaitu Senja. Fajar juga ingin berterimakasih kepada Senja karena telah meminjamkan juz amma itu kepadanya sehingga ia dapat menjadi Fajar yang sekarang.

Berdasarkan data (Iphn/46/1.04) tuturan tersebut termasuk ke dalam tuturan imperatif permohonan karena Fajar memohon kepada Allah lewat sebuah doa agar ia dapat segera dipertemukan dengan Senja. Fajar ingin berterimakasih kepada Senja yang telah meminjamkan juz amma kepadanya sehingga ia dapat menjadi pribadi yang baik seperti saat ini dan lebih dekat dengan Allah, juga ingin memgembalikan juz amma yang telah lama ia pinjam dari Senja. Adapun kutipan data yang mendukung hal tersebut, " $Y a$ Allah pertemukan aku dengan dia, sekali saja. Agar aku bisa mengembalikan juz amma ini kepadanya. Agar aku bisa berterimakasih kepadanya atas kebaikan yang telah dia lakukan padaku dulu, yang membuatku bisa lebih mengenal-Mu.". Selain itu, diperkuat dengan tuturan yang diucapkan oleh Fajar yang memohon kepada Allah melalui sebuah doa agar dapat dipertemukan dengan senja walau hanya sekali.

\section{e. Tuturan Yang Mengandung Makna Pragmatik Imperatif Desakan}

Data : (Id/34/1.05)

Senja : "Aku pernah diajak Mang

Didin main ke IPB bareng Ibu.

Tempatnya bagus dan luaaassss sekali" Fajar : "Waaah kereeen. Kata Mama, aku harus kuliah di IPB.

Biar engga ada yang memanggilku si Miskin lagi"

Senja : "Kamu harus pintar dan semangat kaya Mang didin kalau gitu. Kamu pasti bisa."

Tuturan pada data (Id/34/1.05) dituturkan oleh Senja kepada Fajar agar Fajar lebih giat dan bersemangat lagi dalam belajar sehingga Fajar dapat meraih cita-citanya untuk berkuliah di IPB seperti Mang Didin paman Senja. Fajar pun semakin bersemangat mendengar apa yang dikatakan oleh Senja dan itu dijadikan motifasi oleh Fajar agar ia dapat meraih keinginannya untuk dapat berkuliah di IPB mengikuti jejak paman Senja Mang Didin.

Berdasarkan data (Id/34/1.05) tuturan tersebut termasuk ke dalam tuturan yang mengandung makna pragmatik imperatif desakan karena Senja mendesak agar Fajar lebih rajin dalam belajar dan terus 
semangat agar Fajar dapat mencapai citacitanya untuk berkuliah di IPB . Adapun kutipan data yang mendukung hal tersebut, "Kamu harus pintar dan semangat kaya Mang didin kalau gitu. Kamu pasti bisa". Selain itu, didukung kata "harus" dalam tuturannya yang menjadi penguat dari tuturan imperatif desakan untuk memberi penekanan maksud tuturan tersebut yaitu mendesak Fajar agar terus giat belajar agar dapat mencapai cita-cita yang ia inginkan yakni, berkuliah di IPB seperti paman Senja.

\section{f. Tuturan Yang Mengandung Makna Pragmatik Imperatif Persilaan}

Data : (Ips/124/1.08)

Demoy : "Urusan naon tah?" tanya Demo

Angga : "Urusan dunia akhirat." balas Angga

Demoy : "Asyiik. lamun akhirat mah, ngiluan lah.. Asal jangan politik, saja, it's suck lah. Eh eta saha? Demon melirik ke belakang kepada Satria yang tersenyum tipis."

Angga : "Babaturan urang, teman, namanya Satria,tah kenalkeun."

Satria : Deden dan Satria bersalaman "Perkenalkan saya Satria kata Satria.

Demoy : "Deden Melenoy, panggilan Demoy, manusia seutuhnya keturunan Nabi Adam. anti kemapanan dan anti korupsi Demoy memperkenalkan diri. Satria tersenyum mendengar perkenalan Deden."

Angga dan Satria lalu dipersilakan masuk ke kamar indekos Demoy yang sempit. Mereka duduk dan melanjutkan pembicaraan.

Tuturan pada data (Ips/124/1.08) dituturkan oleh Demoy kepada Angga mengenai apa maksud kedatangan mereka berdua ke indekos Demoy Angga pun menjelaskan bahwa ia ingin membicarakan mengenai urusan dunia akhirat yaitu menanyakan mengenai Kampung Hijrah tempat dimana ayah Senja tinggal dan melakukan perjalanan hijrahnya hingga meninggal dalam keadaan husnul khotimah.

Berdasarkan data (Ips/124/1.08) tuturan tersebut termasuk ke dalam tuturan imperatif persilaan karena setelah mendengar maksud kedatangan Angga dan Satria ke indekosnya, Demoy mempersilakan agar Angga dan juga Satria untuk masuk ke dalam indekosnya dan melanjutkan pembicaraan mereka di dalam. Adapun kutipan data yang mendukung hal tersebut, "Angga dan Satria lalu dipersilakan masuk ke kamar indekos Demoy yang sempit. Mereka duduk dan melanjutkan pembicaraan.". Selain itu, diperkuat dengan adanya kata "dipersilakan" sebagai penanda dari tuturan imperatif persilaan.

\section{g. Tuturan Yang Mengandung Makna Pragmatik Imperatif Ajakan}

Data : (Iajk/13/1.09)

Satria : "Ketemuan Yuk Sore Ini, aku mau mengajakmu mengalahkan rasa takut.

Senja : Oh ya, di mana?

Satria : Skate Park Samping taman Jomblo pukul 16.30.

Tuturan pada data (Iajk/13/1.09) diungkapkan oleh Satria kepada Senja melalui SMS, Satria mengajak Senja jalan ke Skate untuk menunjukkan bagaimana cara mengalahkan rasa takut menurut cara Satria. Adapun caranya dengan bermain skateboard menurut Satria cara itu adalah cara ampuh untuknya melawan rasa takut pada dirinya dan dia ingn mengajarkan itu pada Senja.

Berdasarkan data (Iajk/13/1.09) tuturan tersebut termasuk ke dalam tuturan yang mengandung makna pragmatik imperatif ajakan karena, Satria mengajak Senja pergi ke skate untuk menunjukkan bagaimana cara menghilangkan rasa takut menurut Satria yaitu dengan bermain skate board sepertinya. Menurut Satria itu adalah cara ia untuk menghilangkan rasa takutnya. Adapun kutipan data yang mendukung hal tersebut, "Ketemuan Yuk Sore Ini, aku mau mengajakmu mengalahkan rasa takut". 
Selain itu, didukung oleh kata "Yuk" dari tuturan yang diungkapkan oleh Satria, hal itu cukup memper jelasa bahwa adanya ajakan kepada Senja untuk ikut dengannya ke skate board dengan tujuan agar Senja bisa melihat Satria menunjukkan bagaimana cara melawan rasa takut.

\section{h. Tuturan Yang Mengandung Makna Pragmatik Imperatif Permintaan Izin.}

Data : (Ipi/212/3.10)

Satria : "Oh, Iya, Ma, Satria

boleh kembali ke Kampung Hijrah

besok? Enggak enak kalau izinnya terlalu lama. Enggak apa kan?"

Ibu Satria : "Iya, enggak apa-apa. Mama sudah ambil cuti kerja

seminggu ke depan, jadi bisa jaga adikmu,"

Tuturan pada data (Ipi/212/3.10) dituturkan oleh Satria kepada Ibunya, mengenai Satria yang ingin segera kembali ke Kampung Hijrah karena merasa tidak enak apabila izin terlalu lama, dan Satria menanyakan apakah ia bisa balik hari itu juga ke kampung hijrah pada Ibunya. Ibunya membolehkan Satria untuk balik ke Kampung Hijrah karena ibunya sudah mengambil libur agar dapat menjaga adiknya di rumah.

Berdasarkan data (Ipi/212/3.10) tuturan tersebut termasuk ke dalam tuturan yang mengandung makna pragmatik imperatif permintaan izin karena Satria meminta izin kepada ibunya, apakah ia sudah bisa kembali ke Kampung Hijrah, Satria merasa tidak enak apabila terlalu lama mengambil libur dan ibunya membolehkan Satria untuk dapat kembali lagi ke Kampung Hijrah. Adapun kutipan data yang mendukung hal tersebut, "Oh, Iya, Ma, Satria boleh kembali ke Kampung Hijrah besok? Enggak enak kalau izinnya terlalu lama. Enggak apa kan?". Selain itu, didukung kata "boleh" dalam tuturannya yang menjadi penanda dari tuturan imperatif permintaan izin untuk penekanan maksud tuturan tersebut.

\section{i. Tuturan Yang Mengandung Makna Pragmatik Imperatif Larangan}

Data : (Il/60/3.12)

Ayah : Ayah memang jahat Nak.

Saat itu Ayah khilaf dan gelap mata. Ayah terlalu banyak dosa.

Ayah : "Senja, anakku, mungkin sekarang kamu sangat membenci Ayah. Tapi kamu jangan pernah membenci penciptamu ya, Nak.

Tuturan pada data (Il/60/3.12) diungkapkan oleh ayah Senja kepada Senja untuk tidak pernah membeci Allah sang maha pencipta atas segala perbuatan yang telah dilakukan oleh Ayahnya kepada Senja dan Ibunya di masa lalu yang telah meninggalkan ia dan Ibunya. Hal ini menyebabkan, Senja sangat membenci Ayahnya.

Berdasarkan data (Il/60/3.12) tuturan termasuk ke dalam tuturan imperatif yang mengandung makna pragmatik imperatif larangan karena Ayah senja meminta kepada Senja agar tidak membenci Allah sang maha penciptanya atas segala hal yang telah terjadi dalam hidup Senja dan Ibunya. Ayahnya yang meninggalkan Senja sejak dalam kandungan hingga Senja sangat membenci Ayahnya. Adapun kutipan data yang mendukung hal tersebut, "Tapi kamu jangan pernah membenci penciptamu ya, Nak'. Selain itu, didukung dengan kata "Jangan" dalam tuturannya yang menjadi penegas dari tuturan imperatif larangan untuk memberi penekanan maksud dari tuturan tersebut.

\section{j. Tuturan Mengandung Makna Pragmatik Imperatif Harapan}

Data : (Ih/73/3.13)

Kemarin, Fajar berdiskusi dengan Mama tentang rencana hidupnya di Bandung. Sebelumnya, Fajar memang sempat galau apakah akan melanjutkan kuliah ke jenjang S2 ataukah langsung bekerja? Kebetulan ada lowongan pekerjaan di Bandung yang membuat Fajar tertarik.

Fajar : "Doakan semoga rezekinya Fajar untuk bisa bekerja di bank 
syariah itu, Ma. Kalaupun ternyata tidak diterima, Fajar akan tetap mencoba cari kerja di Bandung".

Tuturan pada data (Ih/73/3.13) dituturkan oleh Fajar mengenai rencana hidupnya kepada mamanya apa bila nantinya ia memang akan tinggal di Bandung karena Fajar berencana akan melamar pekerjaan di Bandung. Fajar sangat berharap ia dapat tinggal dan bekerja di Bandung walau ia ditola bekerja di Bank Syariah Fajar akan berusaha mencari pekerjaan lain yang ada di Bandung.

Berdasarkan tuturan data (Ih/73/3.13) tuturan tersebut termasuk ke dalam tuturan imperatif harapan karena Fajar berharap agar ia dapat bekerja di Bank Syariah yang ada di Bandung dan meminta doa kepada mamanya agar ia dapat diterima bekerja disana, itu adalah keinginan Fajar dapat pekerjaan dan tinggal di Bandung walaupuntidak diterima di Bank Syariah. Fajar akan terus berusaha mencari pekerjaan di Bandung. Adapun kutipan data yang mendukung hal tersebut. "Doakan semoga rezekinya Fajar untuk bisa bekerja di bank syariah itu, Ma. Kalaupun ternyata tidak diterima, Fajar akan tetap mencoba cari kerja di Bandung". Selain itu, didukung kata "semoga" dalam tuturannya yang menjadi penanda dari tuturan imperatif harapan.

\section{KESIMPULAN}

Berdasarkan hasil penelitian dan pembahasan yang dilakukan dan temuan yang diperoleh setelah melakukan analisis dan menjawab rumusan masalah, maka dapat diambil kesimpulan bahwa dari tuturan tokoh dalam novel Hijrah itu Cinta Karya Abay Adhitya ditemukan sebanyak 51 data yang mengandung wujud pragmatik imperatif.

Wujud pragmatik imperatif yang paling banyak ditemukan yaitu tuturan imperatif yang mengandung makna larangan yaitu sebanyak 14 data dengan presentase sebesar $27,4 \%$. Tuturan yang mengandung makna pragmatik larangan cenderung lebih banyak ditemukan karena sang penutur atau tokoh pada novel Hijrah itu Cinta dalam tuturannya cenderung lebih banyak melarang terutama pada hal yang tidak baik seperti ayah Senja yang melarang Senja untuk membenci Allah atas kesalahan yang telah diperbuat oleh ayahnya. "Uztadz Rofik yang mengingatkan Fajar untuk tidak pernah sombong atas ilmu yang ia miliki" dan "Ustadz Ali yang melarang untuk ngejudge sekalipun itu adalah seorang penjahat karena siapa saja bisa berubah menjadi orang baik walaupun pendosa sekalipun". Selain itu, tuturan yang mengandung makna larangan juga terdapat saran-saran dan masukan tentang bagaimana sikap yang seharusnya dilakukan oleh mitra tutur.

Tuturan yang tidak ditemukan yaitu imperatif bujukan, imbauan, mengizinkan, umpatan, pemberian ucapan selamat, anjuran, dan "ngelulu". Hal tersebut dikarenakan tidak adanya penanda dari tuturan imperatif dan konteks yang berkaitan dengan imperatif bujukan, imbauan, mengizinkan, umpatan, pemberian ucapan selamat, anjuran, dan "ngelulu" karena tidak semua dialog maupun narasi yang terdapat dalam novel Hijrah itu Cinta memiliki tuturan imperatif.

Tuturan yang mengandung makna pragmatik imperatif sendiri dapat diartikan sebagai bentuk perintah atau perasaan yang ada dalam diri tokoh untuk menyuarakan pendapatnya, tuturan yang dituturkan oleh penutur atau tokoh diharapkan agar orang dapat melakukan sesuatu seperti yang dimaksudkan oleh penutur. Tingkah laku maupun tutur kata yang ditunjukkan oleh seorang tokoh dalam novel Hijrah itu Cinta dalam tuturannya tidak hanya sekedar menyampaikan apa yang ada dibenaknya saja tetapi juga harus bisa menyesuaikan konteks tuturan agar terciptanya sikap saling menghormati dan menghargai satu sama lain. 


\section{DAFTAR PUSTAKA}

Adhitya, A. (2018). Hijrah Itu Cinta. Yogyakarta: PT Benteng Pustaka.

Al-Humairah, W. M., Retnowaty, R., \& Ratnawati, I. I. (2020). Tindak Tutur pada Iklan Produk Kecantikan di Televisi Swasta. Lingua Franca: Jurnal Bahasa, Sastra, dan Pengajarannya, 4(2), 269-277.

Asrul, Rabi, A., \& Syahrani, A. (2019). Analisis Tuturan Imperatif Pada Media Luar Ruang Di Kabupaten Sambas: Kajian Pragmatik. Jurnal Pendidikan Dan Pembelajaran Khatulistiwa, Vol 8, No.9.

Astuti, F. A., Retnowaty, R., \& Maulida, N. (2020). STRATEGI TINDAK TUTUR PENOLAKAN DALAM INTERAKSI PEDAGANG DAN PEMBELI DI PLAZA KEBUN SAYUR BALIKPAPAN. Bahtera Indonesia; Jurnal Penelitian Bahasa dan Sastra Indonesia, 5(1), 12-26.

Chaer, A. (2010). Kesantunan Berbahasa. Jakarta: PT Rineka Cipta.

Hodairiyah, H., \& Utama, F. F. (2019). Bentuk-Bentuk Kalimat Imperatif Permintaan Pada Iklan Rokok "Djarum 76." Leksema: Jurnal Bahasa Dan Sastra, 4(1), 11.

Rahardi, K. (2005). Pragmatik (Kesantunan Imperatif Bahasa Indonesia). Jakarta: Penerbit Erlangga.

Ramaniyar, E. (2017). Analisis Tuturan Imperatif Dalam Bahasa Melayu Dialek Sintang Kecamatan Serawai Kajian Pragmatik. Jurnal Pendidikan Bahasa, 6(1), 194-208.
Sulhan. (2019). Tindak Tutur Imperatif Dalam Percakapan Sehari-Hari Mahasiswa Program Studi Pendidikan Bahasa Indonesia Universitas Tadulako ( Kajian Pragmatik ). Jurnal Bahasa Dan Sastra Volume 4 No 3 (2019), 4(3), 12

Wahyuni, S. T., \& Retnowaty, R. (2018). Tindak Tutur Ilokusi pada Caption Akun Islami di Instagram. Jurnal Basataka (JBT), 1(2), 11-18. 